\title{
VRIJEDNOSTI OBRAZOVANJA I NASTAVNIČKI IDENTITET IZ UČENIČKE, RODITELJSKE I NASTAVNIČKE PERSPEKTIVE
}

\author{
Marina Diković ${ }^{1}$, Marlena Plavšić ${ }^{2}$ \\ ${ }^{1}$ Sveučilište Jurja Dobrile u Puli, Fakultet za odgojne \\ i obrazovne znanosti, Hrvatska \\ ${ }^{2}$ Sveučilište Jurja Dobrile u Puli, \\ Filozofski fakultet, Hrvatska \\ mdikovic@unipu.hr; mplavsic@unipu.hr
}

Primljeno: 26. 9. 2018.

\begin{abstract}
U Hrvatskoj i svijetu manji je dio nastavničkoga kadra koji smatra da je nastavnička profesija cijenjena. Većina se autora i autorica slaže da bi jačanje nastavničkoga identiteta moglo pomoći podizanju vrijednosti obrazovanja. Ciljevi istraživanja bili su: ispitati na koje načine obrazovanje doprinosi kvaliteti života i koje su prednosti nastavničke profesije, ispitati doživljaj statusa nastavničke profesije i promjena u obrazovnom sustavu te utvrditi motivaciju za nastavničku profesiju. Uzorak je obuhvaćao 74 učenika i učenica osnovnih i srednjih škola, 73 roditelja, 38 studenata i studentica nastavničkih studija te 35 osnovnoškolskih $i$ srednjoškolskih nastavnika i nastavnica. Rezultati se interpretiraju u kontekstu Korthagenovog modela te pokazuju da nastavnici i nastavnice više spominju obilježja nastavničkoga identiteta koja se dotiču temeljnih vrijednosti, dok roditelji $i$ učenici više spominju obilježja ponašanja i kompetencija. Zadaća je inicijalnoga obrazovanja nastavnika i nastavnica poticati mlade na promišljanje o vrijednostima nastavničke profesije jer će time cijeniti i poticati razvijanje vrijednosti nastavničkoga identiteta.
\end{abstract}

Ključne riječi: nastavnička profesija, Korthagenov model, nastavnici, nastavnički identitet, roditelji, učenici

\section{Uvod}

Jedan od načina povećanja kvalitete života, odnosno poboljšanja životnoga standarda upravo je obrazovanje (Maričić, Šakić i Franc, 2009). 
Koliko se cijeni vrijednost obrazovanja, toliko treba njegovati nastavničku profesiju i čuvati dignitet nastavnika i nastavnica ${ }^{1}$ u društvu. To bi trebala biti zadaća samih nastavnika i nastavnica, ali i učenika i učenica, roditelja te studenata i studentica nastavničkih studija. U tom je smislu inicijalno obrazovanje nastavnica i nastavnika kamen temeljac koji potiče studente i studentice na promišljanje o kvaliteti nastavničke profesije, ali i o doprinosu vrijednosti odgoja i obrazovanja koje je, prema istraživanjima, umnogome zanemareno.

O zadovoljstvu školom govore brojni autori i brojne autorice (npr. Jurić, 1995; Baker, 1999; Sharma i Jyoti, 2006). Bez obzira na visok stupanj zadovoljstva obitelji školom (npr. u istraživanju Jurić, 1995), škole bi trebale pronalaziti načine za približavanje obitelji. Također, podrška nastavnica i nastavnika učenicima i učenicama u razrednoj i školskoj zajednici značajno utječe na emocionalni, socijalni i moralni razvoj učenica i učenika (Jagić i Jurčić, 2006; Raboteg-Šarić et al., 2009; Williams i Deci, 1996).

U Hrvatskoj nešto manje od 10 \% nastavnika i nastavnica smatra da je nastavnička profesija cijenjena u društvu (TALIS, 2013). I u svjetskim se razmjerima prepoznaje zabrinutost zbog njezina opadajućeg društvenog statusa te se pokušavaju iznaći načini kako da je se učini dovoljno privlačnom da se mladi ljudi visokih sposobnosti, motivacije i predanosti odluče za nastavničku profesiju te da se u njoj i zadrže (Graham i Phelps, 2003).

Jačanje nastavničkoga identiteta moglo bi pomoći podizanju vrijednosti obrazovanja. Profesionalni (u što se uključuje i nastavnički) identitet Domović i Vizek Vidović $(2013,494)$ definiraju »kao skup vrijednosti, uvjerenja i stavova o odabranom pozivu«. Iste autorice dodaju da profesionalni identitet nije stalan i stabilan fenomen te da uz karakteristike osobe ovisi o radnom i životnom kontekstu i odnosima s drugima, ali i da pojedinci i pojedinke često nisu u potpunosti svjesni vlastitoga i kolektivnoga profesionalnoga identiteta.

»Profesionalni identitet ovisi o okruženjima u kojima nastavnici djeluju i razvijaju se - programima inicijalnoga obrazovanja, školi u kojoj rade, obrazovnoj politici, načinima upravljanja školom, programima stručnoga usavrša-

${ }^{1} \mathrm{U}$ radu se pojam nastavnik/nastavnica odnosi i na učitelje/učiteljice koji rade u osnovnim školama i na nastavnike/nastavnice koji rade u srednjim školama (Zakon o odgoju $i$ obrazovanju u osnovnoj i srednjoj školi, NN 87/08, čl. 100.). 
vanja nastavnika, odnosu javnosti prema obrazovanju.« (Domović i Vizek Vidović, 2013, 495)

Domović (2011) objašnjava da se nastavnička uvjerenja stječu još u razdoblju dok je budući nastavnik u školskoj klupi, ona su emocionalno obojena, trajna i duboko ukorijenjena. Također, tijekom inicijalnoga obrazovanja nastavnica i nastavnika oni mogu biti pod utjecajem racionalnih argumenata i znanstvenih dokaza koji im mogu proturječiti.

Ranđelović i Živković (2013) opisuju profesionalni identitet koji uključuje profesionalnu nastavnu praksu (ono što nastavnici i nastavnice rade) te stručnu ulogu i stavove (ono što su nastavnici sami i što predstavljaju drugima). Oljača, Kostović i Kovačević (2015) sugeriraju dimenzije nastavničkoga profesionalnog identiteta koje se mjere samoevaluacijom: vrijednosne orijentacije, samopoimanje, samopoštovanje i lokus kontrole te efikasnost u nastavi. Interpretirani nalazi ovoga istraživanja upućuju na to da primjenom samorefleksije ili samoanalize nastavnice i nastavnici mogu postati svjesni(ji) složenosti procesa odgoja i obrazovanja, što može dalje dovesti do temeljitijega razumijevanja procesa poučavanja, ali i osobnoga profesionalnog identiteta. A i s obzirom na dinamičnost procesa izgradnje profesionalnoga identiteta zbog usklađivanja s različitim utjecajima i izazovima, nastavnički je identitet najprikladnije istraživati samoevaluacijom (Cooper i Olson, 1996). Nastavnički identitet obilježava i suradnja nastavnika i nastavnica sa stručnim suradnicama i suradnicima, stoga je važno napomenuti da kompetencije školskih pedagoginja i pedagoga i identitet školske pedagoginje / školskoga pedagoga (Ledić, Staničić i Turk, 2013) u tom smislu pojačavaju nastavnički identitet i čine ga prepoznatljivijim u školskoj zajednici i uopće u društvu.

Kao najbolji prediktor u svim aspektima profesionalnoga identiteta u nekim se istraživanjima pokazalo zadovoljstvo profesijom (Ranđelović i Živković, 2013). Korthagen (2004) obrazlaže da profesionalni identitet čine nesvjesne potrebe, osjećaji, vrijednosti, modeli uloga, prethodna iskustva i ponašanja, koji zajedno stvaraju osjećaj identiteta. Nadalje, usmjeravanje na temeljna obilježja i vrijednosti nastavničkoga identiteta te refleksija o njima tijekom nastavničkoga studija studentima i studenticama može pomoći u razumijevanju temeljnih vrijednosti i kvalitete učenika i učenica, ali i u poticanju na razvijanje i najbolji način primjene tih vrijednosti (Korthagen, 2004; Korthagen i Vasalos, 2005). Razni su načini koji potiču promišljanje i refleksije o identitetu 
u nastavničkoj ulozi. Neka od pitanja koja studentima i studenticama, budućim nastavnicima i nastavnicama mogu u tome pomoći odnose se na privlačnost profesije, motivaciju, razmatranje društvenoga konteksta i prepoznavanje vrijednosti obrazovanja. Osobne vrijednosti i ideali, naime, posreduju između vanjskih događaja i načina na koji ih ljudi doživljavaju, a to je ključno za nastavničku profesiju (Peterson i Seligman, 2004).

Nastavničku je profesiju moguće razmatrati iz nekoliko područja koja je na prepoznatljiv način obilježavaju. Jedno se područje odnosi na prednosti nastavničkoga djelokruga rada i doprinos obrazovanja kvaliteti življenja, drugo na promjene koje se događaju u sklopu procesa obrazovanja i statusa nastavničke profesije, dok se treće područje dotiče motivacije za nastavnički posao.

Prepoznavanje prednosti nastavničkoga posla moglo bi biti jedno od temeljnih faktora odabira nastavničke profesije. Mladi ljudi trebaju potvrdu da ono čime će se baviti u svojoj karijeri ima prednosti te bi se time mogla pobuditi i motivacija da budu nastavnici/nastavnice. $U$ refleksiji o svojoj profesiji studentice i studenti mogu se dotaći i doprinosa obrazovanja kvaliteti življenja. Ako prepoznaju da odgoj i obrazovanje pridonose razvoju osobe, osposobljavaju je za kvalitetnije zadovoljavanje potreba, pridonose njezinom samoostvarenju i održivosti (Pastuović, 2012), onda jačaju temeljne vrijednosti profesionalnoga identiteta za koji se školuju. Pastuović (2012) dodaje da ljudska prava, ali i ostale vrijednosti koje se prenose odgojem i obrazovanjem, pridonose kvaliteti života i utječu na gospodarski i politički razvoj društva u kojemu aktivni građani i aktivne građanke razvijaju sebe i zajednicu u kojoj žive. Ulaganje u odgoj i obrazovanje isplati se na objema razinama, kako na individualnoj, tako i na društvenoj (Pastuović, 2012). Na taj će način osoba biti zadovoljna vlastitim obrazovanjem, uočit će smisao odgoja i obrazovanja te će moći aktivno doprinositi sebi i okruženju. Kvaliteta življenja bit će viša ako je osoba odgojem i obrazovanjem pokazala da cijeni društvo temeljeno na znanju.

Što se statusa nastavnika i nastavnica u društvu tiče treba naglasiti da mnoga istraživanja ukazuju na loš društveni status ovih profesija (Bjelajac i Reić, 2006; Jukić i Reić-Ercegovac, 2008; Lučić, 2007; Pavin, Rijavec i Miljević-Riđički, 2005; Radeka i Sorić, 2006). Studentice i studenti nastavničkih studija svjesni su da se nastavnički posao ne cijeni dovoljno (Bjelajac i Reić, 2006; Jukić i Reić-Ercegovac, 2008; 
Lučić, 2007; Šimić Šašić, Klarin i Grbin, 2013), a svojim izborima, vjerovanjima, ponašanjem i radom oni sudjeluju u izgradnji društvenih vrijednosti. Stoga su oni ujedno i pokretačke snage promjena u odgojno-obrazovnom procesu. Odgoj i obrazovanje imaju utjecaj na kulturu nekog društva, oni kulturu učvršćuju ali i mijenjaju, a vrijednosti kulturnoga izražavanja čine snažnijima.

Marušić, Jugović i Pavin Ivanec (prema Šimić Šašić, Klarin i Grbin, 2013) motivaciju za nastavnički posao razvrstavaju u tri kategorije: 1) altruističnu, koja se odnosi na potrebu za pomaganjem, na primjer djeci, uspjehu djece ili šire dobrobiti društva; 2) intrinzičnu, koja se odnosi na to da nastavnice i nastavnici rade nešto što je njima važno i u čemu se osjećaju vrijedno i dobro, kao što je na primjer interes za prenošenjem specifičnoga znanja; i 3) ekstrinzičnu, koja ukazuje na dobitke do kojih nastavnički posao posredno dovodi, na primjer dugi praznici, plaća ili društveni status. Bielby i suradnici (2007) tvrde da su nastavnice i nastavnici za svoj posao prvenstveno motivirani intrinzičnim razlozima, a manje ekstrinzičnim. Čudina-Obradović (2008) utvrdila je intrinzičnu i altruističnu motivaciju kod studentica i studenata nastavničkih studija koja se odnosi na privlačnost nastavničkoga zvanja i želju za rad s djecom. Također, dokazano je da je motivacija profesionalnoga izbora nastavnica i nastavnika značajna za njihov kasniji profesionalni razvoj te da je za uspjeh važno da se studenti i studentice opredjeljuju i pripremaju za nastavničku profesiju od početka inicijalnoga obrazovanja (Marušić, 2014).

Teorijska osnova rada većinom uključuje Korthagenov (2004) model profesionalnoga identiteta nastavnika/nastavnice čiji se razvoj promatra kroz šest slojeva predstavljenih kao šest koncentričnih kružnica od vanjskih, manifestnih do temeljnih, unutrašnjih. Slojevi su, od vanjskih prema unutrašnjima sljedeći: okolina, ponašanje, kompetencije, uvjerenja, (profesionalni) identitet i misija. Najudaljenija je okolina, a ona se odnosi na razred, učenice/učenike ili školu. Ponašanje uključuje ostvarene izvedbe nastavnice/nastavnika. Kompetencije obuhvaćaju znanje, vještine i stavove kao potencijal za istraživanje ponašanja. Ovisno o situaciji, kompetencije se izražavaju u ponašanju. Sljedeća su razina uvjerenja koja nastavnice i nastavnici imaju u vezi s učenjem i poučavanjem. Identitet se odnosi na to kako nastavnici i nastavnice vide svoju profesionalnu ulogu i kakvi u njoj žele biti. Misija, kao najdublja razina, tumači se kao svjesnost značenja vlastitoga postojanja unutar 
širega životnog konteksta. Svaki od ovih slojeva može biti uključen u procjenu nastavničkoga posla, u doživljaj nastavničkoga statusa i obrazovnoga sustava te u određivanju motivacije za bavljenje nastavničkim poslom.

\section{Ciljevi}

Ciljevi rada su:

1) ispitati na koje načine obrazovanje doprinosi kvaliteti života i koje su prednosti nastavničke profesije;

2) ispitati doživljaj statusa nastavničke profesije i promjena u obrazovnom sustavu;

3) utvrditi motivaciju za nastavničku profesiju.

Ti su se ciljevi ispitivali iz nekoliko perspektiva dionika odgojnoobrazovnog procesa: učeničke, studentske, nastavničke i roditeljske.

\section{Metodologija istraživanja}

\section{Sudionici i sudionice}

Uzorak je bio prigodan i obuhvaćao je 220 sudionika i sudionica podijeljenih u četiri grupe: (1) 74 učenika i učenice, (2) 38 studentica i studenata, (3) 73 roditelja te (4) 35 nastavnika i nastavnica. U prvoj je grupi bilo 38 učenika i 36 učenica u dobi od 6 do 19 godina $(M=14.60$, $S D=2.98$ ), od kojih je 36 bilo u osnovnoj, a 38 u srednjoj školi. Druga skupina obuhvatila je 15 studenata i 23 studentice nastavničkih studija u dobi od 20 do 27 godina $(M=21.00, S D=1.51)$. Treća je skupina uključivala 37 majki i 36 očeva u dobi od 25 do 55 godina $(M=43.87$, $S D=5.98)$ čija su djeca u osnovnoj $(n=13)$, srednjoj $(n=40)$ ili obje škole $(n=6)$. Četvrta je skupina obuhvatila 5 nastavnika i 30 nastavnica u dobi od 25 do 64 godina $(M=41.53, S D=9.37)$. Dio ih je bio zaposlen u trenutku istraživanja u osnovnoj $(n=17)$, dio u srednjoj školi $(n=11)$, a dio u obje $(n=4)$.

\section{Instrumenti}

U svrhu identificiranja pozitivnih obilježja obrazovanja i nastavničkoga posla napravljeni su strukturirani intervjui sa sve četiri skupine 
sudionika i sudionica istraživanja da bi se dobile različite perspektive dionika odgojno-obrazovnoga sustava. Sve četiri skupine odgovarale su na šest pitanja otvorenog tipa o: prednostima nastavničkog posla, zadovoljstvu svojim dosadašnjim obrazovanjem, povezanosti obrazovanja i vlastite kvalitete življenja i statusa nastavnika/nastavnica u društvu, namjerama bavljenja nastavničkim poslom i planovima za daljnje obrazovanje. Nastavnici, nastavnice i roditelji imali su još pitanje koje se odnosilo na promjene koje primjećuju u obrazovnom procesu i ljudima koji u njemu sudjeluju otkad su oni išli u školu. Nastavnice i nastavnici imali su još dva pitanja i to o planovima da se nastave baviti nastavničkim poslom te o tome na što su ponosni u dosadašnjem nastavničkom radu. Svi su odgovori zatim kategorizirani. Osim odgovora u intervjuima, prikupljeni su i podaci o spolu i dobi.

\section{Postupak}

Istraživanje je provedeno 2018. godine i imalo je kako znanstvenu tako i obrazovnu svrhu. S ciljem ispitivanja prednosti nastavničkoga posla i doprinosa obrazovanja iz različitih perspektiva dionika obrazovnoga sustava, studentice i studenti nastavničkoga smjera humanističkih znanosti i glazbe trebali su pronaći: po jednoga učenika ili učenicu osnovne i srednje škole, jednoga nastavnika/nastavnicu bilo iz osnovne ili srednje škole, jednu majku djeteta koje ide bilo u osnovnu bilo u srednju školu te jednoga oca čije dijete pohađa bilo osnovnu bilo srednju školu. Zatim su napravili intervjue s njima i zabilježili ih, zajedno s demografskim podacima. Intervju je kao kvalitativna tehnika istraživanja odabran jer je omogućavao studenticama i studentima da imaju neposredan uvid u stavove i motivaciju svojih budućih kolegica i kolega i da ih mogu izravno upitati za pojašnjenja. Intervjui su trajali od 10 do 20 minuta. Za taj su angažman stekli ECTS-e. Sudjelovanje u intervjuu za sugovornice i sugovornike bilo je dobrovoljno, a suglasnost je zatražena usmeno. Odgovori su zabilježeni bez navođenja imena sudionika kako bi se sačuvala privatnost.

\section{Rezultati i rasprava}

\section{Doprinos obrazovanja i prednosti nastavničkoga posla}

Da bi se odgovorilo na prvi cilj, odgovori sudionika i sudionica istraživanja kategorizirani su, njihove su frekvencije navedene u Tabli- 
cama 1-3 i izračunat je hi-kvadrat test. Prednosti nastavničkoga posla grupirane su u pet kategorija (Tablica 1): karakteristike posla (14 kodova), dobitak za nastavnika/nastavnicu (12 kodova), doprinos nastavnice/nastavnika (9 kodova), moć (10 kodova), materijalni uvjeti (15 kodova).

Tablica 1. Prednosti nastavničkog posla

\begin{tabular}{|c|c|c|c|c|}
\hline \multirow[b]{2}{*}{ Rang } & \multicolumn{4}{|c|}{ Perspektiva (frekvencije odgovora) } \\
\hline & $\begin{array}{l}\text { Učenička } \\
(\mathrm{N}=74)\end{array}$ & $\begin{array}{c}\text { Studentska } \\
(\mathrm{N}=\mathbf{3 8})\end{array}$ & $\begin{array}{l}\text { Nastavnička } \\
(\mathbf{N}=35)\end{array}$ & $\begin{array}{c}\text { Roditeljska } \\
(\mathrm{N}=73)\end{array}$ \\
\hline 1. & $\begin{array}{c}\text { doprinos } \\
\text { nastavnika/ce } \\
\text { (31) }\end{array}$ & $\begin{array}{l}\text { karakteristike } \\
\text { posla }(21)\end{array}$ & $\begin{array}{c}\text { karakteristike } \\
\text { posla }(21)\end{array}$ & $\begin{array}{l}\text { materijalni uvjeti } \\
\qquad(42)\end{array}$ \\
\hline 2. & $\begin{array}{c}\text { materijalni uvjeti } \\
\text { (29) }\end{array}$ & $\begin{array}{c}\text { doprinos } \\
\text { nastavnika/ce (18) }\end{array}$ & $\begin{array}{c}\text { doprinos } \\
\text { nastavnika/ce } \\
(20)\end{array}$ & $\begin{array}{c}\text { doprinos } \\
\text { nastavnika/ce } \\
(33)\end{array}$ \\
\hline 3. & $\begin{array}{c}\text { karakteristike } \\
\text { posla }(21)\end{array}$ & $\begin{array}{c}\text { dobitak za } \\
\text { nastavnika/cu (15) }\end{array}$ & $\begin{array}{c}\text { dobitak za } \\
\text { nastavnika/cu } \\
(17)\end{array}$ & $\begin{array}{c}\text { karakteristike } \\
\text { posla }(24)\end{array}$ \\
\hline 4. & moć (14) & $\begin{array}{l}\text { materijalni uvjeti } \\
\qquad(10)\end{array}$ & $\begin{array}{l}\text { materijalni uvjeti } \\
\text { (8) }\end{array}$ & $\begin{array}{c}\text { dobitak za } \\
\text { nastavnika/cu } \\
\text { (11) }\end{array}$ \\
\hline 5. & $\begin{array}{c}\text { dobitak za } \\
\text { nastavnika/cu (7) }\end{array}$ & moć (5) & moć (1) & moć (4) \\
\hline
\end{tabular}

$\chi^{2}=43.984, d f=12, p<0.01$

Hi-kvadrat upućuje na to da se odgovori značajno različito raspodjeljuju. Iz studentske i nastavničke perspektive (Tablica 1) prednosti nastavničkoga posla jednako su poredane po važnosti i odražavaju da je to posao čije prednosti izviru prvenstveno iz njegovih karakteristika, a kao primjer navedene su: Rad s djecom i mladima; Kreativnost, fleksibilnost; Raznolikost, zanimljivost, dinamičnost; Svakodnevno uočavanje rezultata rada; Inovacije u metodama; Individualizirani pristup. Odmah zatim kao prednost navodi se nastavnički doprinos koji je uključivao samu svrhu nastavničkoga posla: Sudjelovanje u stvaranju humane svijesti; Briga o djeci; Mogućnost prepoznavanja talenata; Utjecaj na razvoj djece, prijenos iskustava i znanja; Podrška razvoju samopouzdanosti djece. Prema Korthagenovom modelu (2004) ove dvije najzastupljenije kategorije koje odgovaraju altruističnim i intrinzičnim 
motivima ubrajaju se u najdublju razinu, razinu misije. Slične su odgovore dobile Domović i Vizek Vidović (2013) u istraživanju u kojemu su ispitivale, između ostaloga, uvjerenja studentica nastavničkoga fakulteta o njihovoj budućoj ulozi. Njihovo je dominantno uvjerenje bilo da je uloga nastavnica i nastavnika orijentirana na brigu, gdje se nastavnicu/nastavnika doživljava kao roditelja ili prijateljicu/prijatelja. Učenice, učenici i roditelji također visoko rangiraju nastavnički doprinos, no za razliku od nastavničke i studentske perspektive, njima se vrlo važnima čine materijalni uvjeti kao što su: Siguran posao; Državni posao; Slobodno ljeto, ne radi se cijeli dan; Dobra plaća, redovna primanja; Dobri uvjeti rada; Dovoljno vremena za obitelj, puno praznika; Nema fizičkoga rada. Ovakvi ekstrinzični motivi, prema Korthagenovom modelu (2004) ubrajali bi se u najudaljeniju vanjsku razinu - razinu okoline. Studentice i studenti, kao i nastavnici i nastavnice prepoznaju da i nastavnice i nastavnici imaju dobitke u svom poslu kao što su: Pozitivna energija; Svakodnevno samodokazivanje u prenošenju znanja; Upoznavanje ljudi, suradnja s kolegicama i kolegama; Mogućnost profesionalnoga razvoja, cjeloživotno učenje; Učenje od učenika; Prijateljstva; Taj me posao čini sretnijom, pozitivnijom, boljom. Prema Korthagenovom modelu ove bi se prednosti nastavničkog posla odnosile na unutrašnju razinu - razinu profesionalnoga identiteta. Za roditelje i učenike i učenice to je manje dojmljiva prednost. Za sve odraslije sudionike i sudionice istraživanja moć je najrjeđe spominjana prednost nastavničkoga posla, a ubrojila je odgovore poput: To je cijenjen posao; Postoji samostalnost $i$ sloboda u njegovom obavljanju; Nastavnici i nastavnice su pametni, imaju moć. Iz perspektive najmlađih, ona je nešto više prepoznata, vjerojatno jer je neravnoteža u moći između njih i nastavnika i nastavnica u njihovom doživljaju najveća, a prema Korthagenovom modelu to bi bila razina ponašanja.

Na pitanje čime su zadovoljni u dosadašnjem obrazovanju, sudionici i sudionice dali su odgovore koji su se raspodijelili u pet kategorija (Tablica 2): s ljudima (6 kodova), s metodama i sadržajima (9 kodova), sa školom (3 koda), s dobitkom za sebe (6 kodova), s vrijednošću obrazovanja (3 koda). Izračunat je hi-kvadrat test. 
Tablica 2. Zadovoljstvo dosadašnjim obrazovanjem

\begin{tabular}{|c|c|c|c|c|}
\hline \multirow[b]{2}{*}{ Rang } & \multicolumn{4}{|c|}{ Perspektiva (frekvencije odgovora) } \\
\hline & $\begin{array}{l}\text { Učenička } \\
(\mathrm{N}=70)\end{array}$ & $\begin{array}{l}\text { Studentska } \\
\qquad(\mathbf{N}=\mathbf{3 7})\end{array}$ & $\begin{array}{l}\text { Nastavnička } \\
\quad(\mathbf{N}=\mathbf{3 1})\end{array}$ & $\begin{array}{l}\text { Roditeljska } \\
\quad(\mathrm{N}=61)\end{array}$ \\
\hline 1. & $\begin{array}{c}\text { metodama i } \\
\text { sadržajima (37) }\end{array}$ & $\begin{array}{c}\text { metodama i } \\
\text { sadržajima (19) }\end{array}$ & $\begin{array}{c}\text { metodama i } \\
\text { sadržajima (18) }\end{array}$ & $\begin{array}{c}\text { metodama i } \\
\text { sadržajima (34) }\end{array}$ \\
\hline 2. & ljudima (27) & školom (13) & ljudima (10) & školom (17) \\
\hline 3. & $\begin{array}{c}\text { dobitkom za sebe } \\
\text { (12) }\end{array}$ & ljudima (12) & školom (9) & ljudima (13) \\
\hline 4. & školom (9) & $\begin{array}{c}\text { dobitkom za sebe } \\
\text { (7) }\end{array}$ & $\begin{array}{l}\text { obrazovanjem } \\
\text { kao vrijednošću } \\
\text { (4) }\end{array}$ & $\begin{array}{c}\text { dobitkom za sebe } \\
(10)\end{array}$ \\
\hline 5. & & $\begin{array}{l}\text { obrazovanjem } \\
\text { kao vrijednošću } \\
\text { (1) }\end{array}$ & $\begin{array}{c}\text { dobitkom } \\
\text { za sebe (3) }\end{array}$ & $\begin{array}{c}\text { obrazovanjem } \\
\text { kao vrijednošću } \\
\text { (1) }\end{array}$ \\
\hline
\end{tabular}

$\chi^{2}=21.242, d f=12, p<0.05$

Hi-kvadrat upućuje na to su razlike u raspodjeli odgovora značajne. Više od polovine odgovora svih upitanih (Tablica 2) odnosilo se na zadovoljstvo metodama i sadržajima iz dosadašnjega obrazovanja, a uključivali su: zabavu, opuštenost, metode, pristupe, sadržaje, kvalitetu, pravo predlaganja svoga načina rada, dobra i loša iskustva. Ovako visoko ocijenjene metode i sadržaji govore u prilog tome da školovanje ostavlja pozitivan dojam u onome što $i$ jesu njegove osnovne djelatnosti - obrazovanje i odgoj. Visoko su rangirani i ljudi koji su obrazovanje činili vrijednim, ugodnim i zabavnim procesom, bilo nastavnici i nastavnice, bilo prijatelji i prijateljice. U istraživanjima je uvelike potvrđeno da podrška nastavnika i nastavnica učenicima i učenicama u razrednoj i školskoj zajednici značajno pozitivno utječe na emocionalni, socijalni i moralni razvoj učenika i učenica (Jagić i Jurčić, 2006; Raboteg-Šarić et al., 2009; Williams i Deci, 1996). Zadovoljstvo obrazovanjem kao vrijednošću ogledalo se u odgovorima koji su ukazivali na njegovu važnost i na to da ga nikad ne može biti dosta. Ovaj se odgovor rjeđe spominjao, kao i zadovoljstvo zbog dobitka za sebe (npr. Jer je besplatno; Zbog mogućnosti putovanja; Zbog povećanja samopouzdanja; Zbog omogućavanja daljnjega školovanja.). Srednje prisutan odgovor bio je onaj koji je uključivao navođenje konkretnih škola, a imenovan je kao 
zadovoljstvo školom (npr. Osnovno obrazovanje do 4. razreda; Studiranje u Puli;...).

Odgovori nastavnika i nastavnica $(n=34)$ o tome na što su ponosni u nastavničkom poslu grupirali su se u tri kategorije. Na prvom je mjestu ponos na uspjehe učenica i učenika (18 odgovora), zatim na odnos koji imaju ili su imali s učenicima i učenicama (11 odgovora) te na ponašanje učenica i učenika prema njima (5 odgovora). Povezujući rezultate s Korthagenovim modelom (2004) najviše odgovora bilo je na razini kompetencija. Budući da je nastavnički posao usko povezan s ishodima učenja, onda je ovakav odgovor usklađen s onime što nastavnici i nastavnice imaju kao zadatak. Njihovi učenici i učenice trebaju doseći konkretne i mjerljive ishode učenja (Kraiger, Ford i Salas, 1993; Bakkenes, Vermunt i Wubbels, 2010) i kad ih vide ostvarenima, ponosni su na svoj posao. Odgovori o odnosu i ponašanju učenika i učenica prema njima, uspoređujući s istim modelom, svrstali bi se na razinu uvjerenja jer nastavnice i nastavnici smatraju da je važno usmjerenje na učenike i učenice i na razvijanje dobrih odnosa. Uvjerenja se nalaze u sržnim razinama Korthagenovog modela jer određuju kako nastavnice i nastavnici interpretiraju situacije s učenicima i učenicama, a to je ključno za nastavničku profesiju (Peterson i Seligman, 2004).

Na pitanje kako je obrazovanje pridonijelo kvaliteti njihova života, dobiveni su odgovori koji su se svrstali u šest kategorija (Tablica 3): doprinos životnoj sigurnosti (14 kodova), spoznajni doprinos (10 kodova), doprinos vrijednostima (5 kodova), doprinos razvoju ličnosti i emocija (6 kodova), doprinos ponašanju (7 kodova), doprinos socijalnom životu (7 kodova). Izračunat je hi-kvadrat test.

Tablica 3. Obrazovanje kao doprinos kvaliteti življenja

\begin{tabular}{|c|c|c|c|c|}
\hline \multirow[b]{2}{*}{ Rang } & \multicolumn{4}{|c|}{ Perspektiva (frekvencije odgovora) } \\
\hline & $\begin{array}{l}\text { Učenička } \\
(\mathrm{N}=72)\end{array}$ & $\begin{array}{l}\text { Studentska } \\
(\mathbf{N}=35)\end{array}$ & $\begin{array}{l}\text { Nastavnička } \\
\quad(\mathrm{N}=34)\end{array}$ & $\begin{array}{l}\text { Roditeljska } \\
\quad(\mathrm{N}=66)\end{array}$ \\
\hline 1. & $\begin{array}{c}\text { doprinos životnoj } \\
\text { sigurnosti (50) }\end{array}$ & $\begin{array}{c}\text { doprinos životnoj } \\
\text { sigurnosti (22) }\end{array}$ & $\begin{array}{c}\text { doprinos životnoj } \\
\text { sigurnosti }(22)\end{array}$ & $\begin{array}{c}\text { doprinos životnoj } \\
\text { sigurnosti (43) }\end{array}$ \\
\hline 2. & $\begin{array}{c}\text { spoznajni } \\
\text { doprinos (16) }\end{array}$ & $\begin{array}{c}\text { spoznajni } \\
\text { doprinos (13) }\end{array}$ & $\begin{array}{c}\text { doprinos } \\
\text { vrijednostima (11) }\end{array}$ & $\begin{array}{c}\text { spoznajni } \\
\text { doprinos (14) }\end{array}$ \\
\hline 3. & $\begin{array}{c}\text { doprinos } \\
\text { vrijednostima (14) }\end{array}$ & $\begin{array}{l}\text { doprinos razvoju } \\
\text { ličnosti i emocija } \\
\text { (9) }\end{array}$ & $\begin{array}{l}\text { doprinos razvoju } \\
\text { ličnosti i emocija } \\
\text { (8) }\end{array}$ & $\begin{array}{c}\text { doprinos } \\
\text { vrijednostima (13) }\end{array}$ \\
\hline
\end{tabular}




\begin{tabular}{|c|c|c|c|c|}
\hline \multirow[b]{2}{*}{ Rang } & \multicolumn{4}{|c|}{ Perspektiva (frekvencije odgovora) } \\
\hline & $\begin{array}{c}\text { Učenička } \\
(\mathrm{N}=72)\end{array}$ & $\begin{array}{c}\text { Studentska } \\
(\mathrm{N}=35)\end{array}$ & $\begin{array}{c}\text { Nastavnička } \\
(\mathbf{N}=34)\end{array}$ & $\begin{array}{c}\text { Roditeljska } \\
(\mathrm{N}=66)\end{array}$ \\
\hline 4. & $\begin{array}{c}\text { doprinos } \\
\text { ponašanju (13) }\end{array}$ & $\begin{array}{c}\text { doprinos } \\
\text { ponašanju (8) } \\
\text { i vrijednostima } \\
\text { (8) }\end{array}$ & $\begin{array}{c}\text { doprinos } \\
\text { socijalnom životu } \\
\text { (7) i spoznajni (7) }\end{array}$ & $\begin{array}{l}\text { doprinos razvoju } \\
\text { ličnosti i emocija } \\
\text { (9) }\end{array}$ \\
\hline 5. & $\begin{array}{c}\text { doprinos } \\
\text { socijalnom životu } \\
(6)\end{array}$ & $\begin{array}{c}\text { doprinos } \\
\text { socijalnom životu } \\
(5)\end{array}$ & $\begin{array}{c}\text { doprinos } \\
\text { ponašanju (4) }\end{array}$ & \begin{tabular}{|c|} 
doprinos \\
socijalnom životu \\
$(8)$
\end{tabular} \\
\hline 6. & $\begin{array}{l}\text { doprinos razvoju } \\
\text { ličnosti i emocija } \\
\text { (4) }\end{array}$ & & & $\begin{array}{c}\text { doprinos } \\
\text { ponašanju (7) }\end{array}$ \\
\hline
\end{tabular}

$\chi^{2}=14.833, d f=15, p>0.05$

Hi-kvadrat upućuje na to da raspodjela odgovora nije značajno različita. Uvjerljivo najčešći odgovor svih upitanih (Tablica 3) bio je da je obrazovanje doprinijelo životnoj sigurnosti, što je uključivalo odgovore poput: Životna sigurnost; Uči se o svemu za život; Bolja plaća, status u društvu; Bolja kvaliteta života, budućnost; Profesionalne kompetencije. Osim nastavnica i nastavnika, svi su ostali na drugom mjestu po učestalosti isticali spoznajni doprinos u kojemu su navodili da je obrazovanje pridonijelo njihovom razmišljanju, mnogim spoznajama o životu, sudjelovanju u raspravama, shvaćanju općenitih stvari, gledanju problema iz različitih perspektiva, kreativnom rješavanju problema, širenju vokabulara, općoj kulturi, novim vidicima. Moguće je da je nastavnicama i nastavnicima spoznajni doprinos obrazovanja nešto što je njegova osnovna svrha, pa su naglašavali ostale doprinose. Srednje često navedeni odgovor bio je doprinos obrazovanja vrijednostima koje sudionici i sudionice istraživanja prepoznaju, a to su spominjali navodeći etičke principe, znanje kao nešto što im nitko ne može oduzeti, ili pak vjerovanjem da je znanjem moguće postići sve. Dok se iz učeničke perspektive najrjeđe navodi, iz ostalih je perspektiva često spominjan doprinos obrazovanja razvoju ličnosti i emocija. Odgovori u kojima svi oni prepoznaju da je obrazovanje pridonijelo tome da postanu bolje osobe, da su zadovoljniji, sigurniji, kompetentniji, zreliji. Uvid u razvoj i faktore razvoja vlastite ličnosti slabije je razvijen u mlađoj dobi u kojoj su još učenici i učenice u odnosu na odrasliju dobi. Doprinos obrazovanja socijalnom životu rjeđe 
se spominjao u svim grupama sudionika i sudionica istraživanja. On je zahvatio odgovore koji su se odnosili na socijalizaciju, zdravije odnose s ljudima, pomaganje drugima, dijeljenje, suradnju, druženje, odgoj vlastite djece, pa i napredak cijele društvene zajednice. Doprinos obrazovanja ponašanju najrjeđe su navodili odrasli sudionici i sudionice, a nešto češće učenice, učenici, studentice i studenti. Vjerojatno je neposredna korist od obrazovanja njima bila najuočljivija, dok su stariji ista ponašanja pripisivali vjerojatno stečenom iskustvu. Odgovori koji su se čuli išli su u prilog tome da je obrazovanje pridonijelo njihovoj organiziranosti, poticaju na različite stvari, snalažljivosti, mogućnostima primjene u svakodnevnom životu, pristojnom ponašanju, strpljivosti, upornosti.

Ukupno razmatrajući odgovore vezane za prednosti nastavničkoga posla i doprinos obrazovanja moguće je uočiti da se iz perspektiva različitih dionika odgojno-obrazovnog sustava prepoznaju brojne prednosti, zadovoljstvo i doprinos u onim temeljnim zadaćama koje imaju i nastavnički posao i obrazovanje, a to je pridonijeti kvaliteti života tijekom i nakon formalnoga obrazovanja. Ovi odgovori podržavaju pretpostavku da se ulaganje u odgoj i obrazovanje isplati kako na individualnoj, tako i na društvenoj razini (Pastuović, 2012). Za studentice i studente koji se školuju za nastavničku profesiju, ali i za nastavnike i nastavnice u procesima refleksije o nastavničkom identitetu ovakve spoznaje mogu pomoći u učvršćivanju motivacije da nastave sa školovanjem, odnosno da se nastave baviti poslom koji dugoročno pridonosi dobrobiti djece i mladih, pa tako i dobrobiti društva.

\section{Doživljaj statusa nastavničke profesije i promjena и obrazovnom sustavu}

Da bi se odgovorilo na drugi cilj, odgovori sudionika i sudionica istraživanja kategorizirani su i njihove su frekvencije navedene $u$ Tablicama 4 i 5 . O sadašnjem doživljaju statusa nastavničke profesije sudionice i sudionici istraživanja izjasnili su se kroz tri distinktivne kategorije (Tablica 4) i izračunat je hi-kvadrat test. 
Tablica 4. Doživljaj statusa nastavničke profesije

\begin{tabular}{|c|c|c|c|c|}
\hline \multirow{2}{*}{ Status } & \multicolumn{4}{|c|}{ Perspektiva (frekvencije odgovora) } \\
\cline { 2 - 5 } & $\begin{array}{c}\text { Učenička } \\
(\mathbf{N = 7 0 )}\end{array}$ & $\begin{array}{c}\text { Studentska } \\
(\mathbf{N}=\mathbf{3 7})\end{array}$ & $\begin{array}{c}\text { Nastavnička } \\
(\mathbf{N = 3 5 )}\end{array}$ & $\begin{array}{c}\text { Roditeljska } \\
(\mathbf{N}=\mathbf{7 1})\end{array}$ \\
\hline Dobar & 28 & 8 & 3 & 23 \\
\hline Srednji & 19 & 11 & 11 & 15 \\
\hline Loš & 23 & 18 & 21 & 33 \\
\hline
\end{tabular}

$\chi^{2}=14.375, d f=6, p<0.05$

Hi-kvadrat test pokazuje da se raspodjela frekvencija odgovora značajno razlikuje. Svi osim učenika i učenica najčešće smatraju da je status nastavnika i nastavnica u društvu loš, potcijenjen, obezvrijeđen, bez poštovanja, nezavidan, neozbiljno shvaćen, s premalom plaćom, sa sve manje prava (Tablica 4). Ovakav doživljaj nastavničkoga statusa potvrđuje nalaze istraživanja provedenih u Hrvatskoj (TALIS, 2013; Kalin, Čepić i Šteh, 2017) što upućuje na zabrinutost zbog neprivlačnosti nastavničkoga zanimanja za mlade ljude koji imaju visoke kapacitete da se odluče za njega. Učenici i učenice, s druge strane, najčešće na status nastavnika i nastavnica gledaju kao na dobar jer ih smatraju uzorom i pametnima, sa znanjem o različitim područjima. No sljedeći je po redu već odgovor da je njihov status loš. Roditelji kao drugi najčešći odgovor navode da je status nastavnika i nastavnica dobar, navodeći prednosti stalnoga posla, teškoće u dobivanju otkaza, redovita primanja, mogućnost borbe za svoja prava (štrajk), a navode i pozitivan utjecaj na razvoj djece i doprinos zajednici. Iz studentske i nastavničke perspektive status nastavnika i nastavnica uvjerljivo se najrjeđe prepoznaje kao dobar. Procjena statusa kao (o)srednjeg češće se pojavljivala u odgovorima iz studentske i nastavničke perspektive, dok je bila najrjeđa kod roditelja i učenika i učenica. Ti su odgovori obično uključivali opise poput: Nije određeni status; Kao i drugi; Moglo bi biti bolje; Osrednji.

O promjenama u obrazovnom sustavu u odnosu na vrijeme kada su oni išli u školu i danas upitani su samo nastavnici/nastavnice i roditelji, kao osobe koje mogu usporediti obrazovni sustav iz dviju vremenskih točaka udaljenih najmanje nekoliko godina, odnosno iz dviju perspektiva: nekadašnje učeničke i sadašnje roditeljske odnosno nastavničke. Dakako, neki od ispitivanih nastavnika i nastavnica su i roditelji, a neki od roditelja imali su i nešto nastavničkoga iskustva. No nisu bili upitani da nužno gledaju na obrazovni sustav kroz te svoje uloge, već da 
identificiraju promjene. Odgovori na pitanje o promjenama podijeljeni su u tri kategorije (Tablica 5): odnosi (23 koda), materijalni uvjeti (8 kodova) i programi (25 kodova). Izračunat je hi-kvadrat test.

Tablica 5. Promjene u obrazovnom sustavu

\begin{tabular}{|c|c|c|}
\hline \multirow{2}{*}{ Rang } & \multicolumn{2}{|c|}{ Perspektiva (frekvencije odgovora) } \\
\cline { 2 - 3 } & Nastavnička (N=31) & Roditeljska $(\mathbf{N}=\mathbf{7 1})$ \\
\hline 1. & odnosi (23) & odnosi (47) \\
\hline 2. & materijalni uvjeti (17) & programi (33) \\
\hline 3. & programi (12) & materijalni uvjeti (22) \\
\hline
\end{tabular}

$\chi^{2}=2.723, d f=2, p>0.05$

Hi-kvadrat ne upućuje na to da su razlike među odgovorima značajne. Najčešći se odgovor (Tablica 5) iz obje perspektive doticao promjena u odnosima nekad i sad, bilo između nastavnika i nastavnica i učenika i učenica, bilo između roditelja i djece. I roditelji i nastavnice i nastavnici ilustrirali su to brojnim primjerima: Prije su nastavnice $i$ nastavnici bili stroži; Nastavnici i nastavnice su danas prisniji s djecom; Prije je bilo više zabave i opuštenosti; Danas je više djece s teškoćama uključeno u redovne razrede; Djeca su bila drugačija; Roditelji su danas zaštitnički prema djeci; Prije se nastavnike i nastavnice više cijenilo; Danas je odgoj liberalniji, nekad je bilo strahopoštovanje; Danas nije dozvoljeno fizički kažnjavati djecu; Danas je više u središtu učenik, a ne nastavnik; Ovlasti djece danas su sve veće, a nastavnika i nastavnica sve skromnije. Promjene materijalnih uvjeta primijećene su u tome da: Nekad su djeca išla u školu pješice, a sada ih se vozi; Danas su prisutne nove tehnologije i poboljšani su uvjeti; Zamjetan je informatički napredak. Promjene prepoznate u programima ubrajale su: Promjene udžbenika, metodika, normi, nekih predmeta (npr. uvođenje vjeronauka); Veća individualiziranost nastave; Veća težina školske torbe; Više je izbornih predmeta; Više je gradiva; Više su intelektualne razine; Više je traženja prečice prema znanju, a manje se čitaju knjige; Manje je vremena za igru; Niže su emocionalne, socijalne $i$ etičke razine. Iako nisu bili upitani o tome doživljavaju li te promjene poboljšanjima ili pogoršanjima, i nastavnici i nastavnice, kao i roditelji, spontano su ih u nekim slučajevima takvima procjenjivali, ali nije bilo moguće zaključiti kakvih je više. 
Gledajući odgovore vezane uz obrazovni proces i status nastavničke profesije u kontekstu društva i kontekstu promjena, može se primijetiti da svi osim učenika i učenica smatraju da status nastavničke profesije uglavnom nije cijenjen, a roditelji, nastavnice i nastavnici mogu lako prepoznati obrazovni sustav kao promijenjen danas u odnosu na razdoblje kad su se oni formalno školovali. U segmentu obrazovanja budućih nastavnika i nastavnica refleksije o promjenama svakako trebaju sačinjavati njegov sastavni dio. Nastavnik/nastavnica element je dinamičnog i promjenjivog sustava i samo u ovom istraživanju neospornost te dinamike nedvojbeno upućuje na potrebu za fleksibilnošću u doživljavanju i provedbi nastavničke profesije i nastavničkog identiteta.

\section{Motivacija za nastavnički posao i obrazovanje}

Da bi se odgovorilo na treći cilj, odgovori sudionika i sudionica istraživanja kategorizirani su i njihove su frekvencije navedene u Tablicama 6-8. O namjerama da se bave nastavničkim poslom upitani su svi osim nastavnika i nastavnica, a odgovori su se mogli raspodijeliti u pet kategorija (Tablica 6): nerado i ne zna (6 kodova), nema zbog vanjskih razloga (7 kodova), nema zbog unutrašnjih razloga ( 3 koda), ima zbog moći i vanjskih razloga (7 kodova), ima zbog karakteristika posla (6 kodova). Izračunat je hi-kvadrat test.

Tablica 6. Namjere bavljenja nastavničkim poslom

\begin{tabular}{|c|c|c|c|}
\hline \multirow{2}{*}{ Rang } & \multicolumn{3}{|c|}{ Perspektiva (frekvencije odgovora) } \\
\hline & Učenička $(\mathrm{N}=74)$ & Studentska $(\mathrm{N}=38)$ & Roditeljska $(\mathrm{N}=73)$ \\
\hline 1. & $\begin{array}{l}\text { Nema, zbog unutrašnjih } \\
\text { razloga }(30)\end{array}$ & $\begin{array}{c}\text { Ima, zbog karakteristika } \\
\text { posla }(20)\end{array}$ & $\begin{array}{c}\text { Nema, zbog unutrašnjih } \\
\text { razloga (31) }\end{array}$ \\
\hline 2. & $\begin{array}{c}\text { Ima, zbog karakteristika } \\
\text { posla }(15)\end{array}$ & Nerado i ne zna (12) & $\begin{array}{c}\text { Ima, zbog karakteristika } \\
\text { posla (18) }\end{array}$ \\
\hline 3. & $\begin{array}{l}\text { Nema, zbog vanjskih } \\
\text { razloga (13) }\end{array}$ & $\begin{array}{c}\text { Ima, zbog moći i } \\
\text { vanjskih razloga (3) }\end{array}$ & $\begin{array}{l}\text { Nema, zbog vanjskih } \\
\text { razloga }(11)\end{array}$ \\
\hline 4. & Nerado i ne zna (10) & $\begin{array}{l}\text { Nema, zbog vanjskih } \\
\text { razloga }(2)\end{array}$ & Nerado i ne zna (8) \\
\hline 5. & $\begin{array}{c}\text { Ima, zbog moći i } \\
\text { vanjskih razloga (6) }\end{array}$ & $\begin{array}{c}\text { Nema, zbog unutrašnjih } \\
\text { razloga (1) }\end{array}$ & $\begin{array}{c}\text { Ima, zbog moći i } \\
\text { vanjskih razloga (2) }\end{array}$ \\
\hline
\end{tabular}

$\chi^{2}=35.032, d f=8, p<0.05$ 
Hi-kvadrat upućuje na to da se frekvencije odgovora značajno razlikuju. Budući da se školuju za nastavnike i nastavnice, ovdje studentice i studenti odskaču s planovima da bi se bavili nastavničkim poslom i za to navode najčešće karakteristike posla kao razloge (Tablica 6): Častan je i lijep posao; Odličan je za upoznavanje ljudskih osobina; To je izazov; Mogu nekog poučiti nečemu. Prema Korthagenovom modelu (2004) to su razlozi koji se odnose na unutrašnje slojeve: misiju i profesionalni identitet. I roditelji, učenici i učenice navode te razloge kada bi se odlučili za nastavnički posao, no njihov je najčešći odgovor da se ne bi bavili nastavničkim poslom zbog unutrašnjih razloga poput: Ne želim izlaziti iz svoje zone udobnosti; Ne smatram se uzorom za djecu; To nije za mene; Nisam veliki autoritet. Budući da predstavljaju temeljno odstupanje upravo od razina misije i nastavničkog profesionalnog identiteta, i ovi bi se odgovori mogli prepoznati unutar Korthagenovog modela, samo suprotnog predznaka. Vanjski razlozi protiv bavljenja nastavničkim poslom kod roditelja, učenica i učenika rangirani su na sredini, a obuhvaćali su odgovore kao što su: Monotono je; Učenici $i$ učenice ponekad teško razumiju gradivo; Djeca su sve agresivnija, a profesorice i profesori nemoćniji; Velika je odgovornost; Posao je stresan. Kod studentica i studenata obje su kategorije odgovora protiv bavljenja nastavničkim poslom najniže rangirane, što bi i trebalo biti očekivano s obzirom na to da su odabrali nastavnički smjer studija. No njihov je drugi odgovor po čestini ne znam i nerado koji je elaboriran obično kao: Da, ali nije mi prvi izbor. Otprilike trećina studentica i studenata koji studiraju humanističke znanosti i glazbu u ovom istraživanju vrlo je vjerojatno upisala nastavnički smjer studija samo kao mogućnost, ali ne i kao želju za bavljenje nastavničkim poslom. Roditelji koji su odgovorili ne znam ili nerado ponudili su pojašnjenje: $D a$, u slučaju da ne mogu obavljati svoj posao, učio bih druge da ga obavljaju; Mogao bih, ima i težih poslova. No oni su, kao i učenice i učenici rjeđe dali taj odgovor, a češće su imali kategorični stav protiv bavljenja nastavničkim poslom. Roditelje, učenike i učenice nastavničkom poslu najslabije bi privukli moć $i$ vanjski razlozi kao što su: Velika mogućnost zapošljavanja; Česta putovanja; Puno slobodnog vremena; Jer vole biti vođe; Jer nastavnici i nastavnice imaju moć. I studenticama i studentima to bi bio slabiji motivacijski faktor za nastavničku profesiju. U skladu s Korthagenovim modelom (2004) to bi bili vanjski slojevi.

Samo nastavnicama i nastavnicima bila su upućena tri pitanja: o tome kada su se odlučili za tu profesiju, zašto ili kako su se odlučili za 
nju te imaju li je namjeru napustiti (Tablica 7). Razlozi za bavljenje nastavničkim poslom grupirani su u četiri kategorije: zbog karakteristika posla (3 koda), na poticaj drugih ( 2 koda), slučajno (3 koda) i ostalo (4 koda). Razlozi za napuštanje nastavničkog posla raspodijeljeni su također u četiri kategorije: ne (1 kod), ne jer vole svoj posao (1 kod), samo u ekstremnim uvjetima (3 koda) te da, da je situacija drugačija (2 koda).

Tablica 7. Bavljenje nastavničkim poslom iz nastavničke perspektive

\begin{tabular}{|c|c|c|c|}
\hline \multirow{2}{*}{ Rang } & \multicolumn{3}{|c|}{$\begin{array}{l}\text { Planovi vezani za nastavnički posao } \\
\text { (frekvencije odgovora) }\end{array}$} \\
\hline & $\begin{array}{c}\text { Kada su se odlučili } \\
\text { njime baviti? }(\mathbf{N}=35)\end{array}$ & $\begin{array}{c}\text { Zašto/kako su se } \\
\text { odlučili njime baviti? } \\
(\mathrm{N}=32)\end{array}$ & $\begin{array}{l}\text { Namjeravaju li ga } \\
\text { napustiti? }(N=35)\end{array}$ \\
\hline 1. & u srednjoj školi (12) & $\begin{array}{l}\text { zbog karakteristika } \\
\text { posla (12) }\end{array}$ & $\begin{array}{c}\text { ne jer vole svoj posao } \\
(15)\end{array}$ \\
\hline 2. & $\begin{array}{l}\text { u osnovnoj školi (7); } \\
\text { dok su radili neki drugi } \\
\text { posao (7) }\end{array}$ & $\begin{array}{l}\text { na poticaj drugih }(8) ; \\
\text { slučajno }(8)\end{array}$ & $\begin{array}{l}\text { ne (9); samo u } \\
\text { ekstremnim uvjetima (9) }\end{array}$ \\
\hline 3. & oduvijek (5) & ostalo (4) & $\begin{array}{c}\text { da, da je situacija } \\
\text { drugačija (2) }\end{array}$ \\
\hline 4. & $\begin{array}{l}\text { tijekom ili koncem } \\
\text { studija (4) }\end{array}$ & & \\
\hline
\end{tabular}

Nastavnice i nastavnici u ovom uzorku odlučili su se za tu profesiju većinom u srednjoj školi, a dosta ih je o tome imalo ideju još i ranije (Tablica 7). Najviše ih se odlučilo za nastavnički poziv zbog karakteristika posla, i to: Zbog velike stvaralačke i pokretačke snage; Zbog komunikacije s djecom; Zbog ljubavi prema predmetu. Nešto manje ih navodi da su se odlučili na to na poticaj drugih kao što su drugi profesori i druge profesorice ili promatranjem drugih nastavnika i nastavnica. Podjednako ih je izjavilo da su u nastavničkim vodama završili slučajno, ne planirajući se time baviti. Nastavnici i nastavnice u ovom pozitivno orijentiranom uzorku naveli su da ne bi napustili taj posao, osim u nekim ekstremnim uvjetima kao što su bolest, financije ili nesposobnost daljnjeg bavljenja njime. Budući da je uzorak bio prigodan, očito je da su njime bili obuhvaćeni nastavnici i nastavnice sa snažnom intrinzičnom motivacijom da se bave poslom koji ih je oduvijek privlačio zbog svojih glavnih obilježja. Prema 
Korthagenovom modelu (2004) to su unutrašnje razine nastavničkog identiteta, razine misije, profesionalnog identiteta i vrijednosti. Kada se to ostvaruje na poslu, nastavnici i nastavnice imaju veći osjećaj pripadanja poslu i manju motivaciju da taj posao napuste (Skaalvik i Skaalvik, 2011).

Ponovno su sve sudionice i svi sudionici bili upitani o željama da se dalje obrazuju. Odgovori su se mogli grupirati u pet kategorija (Tablica 8): nemam (4 koda), ne znam (1 kod), nastavak školovanja (4 koda), cjeloživotno učenje (4 koda) te konkretni programi (30 kodova). Zbog više od 20 posto odgovora s frekvencijama manjim od 5, hi-kvadrat test nije se računao.

Tablica 8. Želje za daljnjim obrazovanjem

\begin{tabular}{|c|c|c|c|c|}
\hline \multirow[b]{2}{*}{ Rang } & \multicolumn{4}{|c|}{ Perspektiva (frekvencije odgovora) } \\
\hline & $\begin{array}{c}\text { Učenička } \\
(\mathrm{N}=71)\end{array}$ & $\begin{array}{l}\text { Studentska } \\
\qquad(\mathbf{N}=\mathbf{3 8})\end{array}$ & $\begin{array}{c}\text { Nastavnička } \\
\quad(\mathbf{N}=\mathbf{3 4})\end{array}$ & $\begin{array}{l}\text { Roditeljska } \\
\quad(N=71)\end{array}$ \\
\hline 1. & $\begin{array}{c}\text { nastavak } \\
\text { školovanja (63) }\end{array}$ & $\begin{array}{c}\text { konkretni } \\
\text { programi (18) }\end{array}$ & $\begin{array}{c}\text { konkretni } \\
\text { programi (13) }\end{array}$ & $\begin{array}{c}\text { konkretni } \\
\text { programi (39) }\end{array}$ \\
\hline 2. & ne znam (4) & $\begin{array}{c}\text { nastavak } \\
\text { školovanja (13) }\end{array}$ & nemam (10) & nemam (18) \\
\hline 3. & nemam (3) & nemam (3) & $\begin{array}{l}\text { cjeloživotno } \\
\text { učenje (5) }\end{array}$ & $\begin{array}{c}\text { cjeloživotno } \\
\text { učenje (8) }\end{array}$ \\
\hline 4. & $\begin{array}{c}\text { cjeloživotno } \\
\text { učenje (1) }\end{array}$ & ne znam (2) & $\begin{array}{c}\text { nastavak } \\
\text { školovanja (4) }\end{array}$ & $\begin{array}{c}\text { nastavak } \\
\text { školovanja (5) }\end{array}$ \\
\hline 5. & & $\begin{array}{l}\text { cjeloživotno } \\
\text { učenje (1) }\end{array}$ & ne znam (2) & ne znam (1) \\
\hline
\end{tabular}

Navedeni odgovori slijede dvije perspektive. Iz perspektive onih koji su u tijeku istraživanja bili uključeni u formalno obrazovanje, osnovno, srednje ili visoko, najčešći odgovori odnosili su se na planove njihovoga nastavka školovanja bilo kroz navođenje srednje škole, preddiplomskoga, diplomskoga ili poslijediplomskoga studija, bilo kroz neke konkretne programe koje su kao dopunu obrazovanju navodili sadašnji studenti i sadašnje studentice. Odgovori da ne znaju ili da nemaju planove vrlo rijetko su se spominjali. U jednom ranijem istraživanju mnogo više studentica i studenata odgojno-obrazovnih znanosti 
izjasnilo se da po završetku studija ne planira nastaviti s obrazovanjem. Njih 60,7\% izjavilo je da ne planira nastaviti s formalnim obrazovanjem, 66,7 \% s neformalnim i 70,9 \% s informalnim učenjem (Plavšić i Diković, 2016). Moguće je da je razlika u tome što ih se u tom istraživanju pitalo o planovima, pa su njihovi odgovori bili fokusirani na ono što stvarno imaju u vidu u (skorijoj) budućnosti, dok je u ovom radu pitanje ostalo u sferi želja koje su manje obvezujuće.

Druga uočljiva perspektiva uključivala je odgovore odraslih osoba - roditelja, nastavnika i nastavnica. Oni su navodili najviše da se žele obrazovati u vrlo različitom spektru konkretnih programa koji su uključivali društvena, prirodoslovna, informacijska, tehnička, zdravstvena, humanistička i umjetnička područja. Češće nego mlađi, oni su navodili i da se nemaju želju dalje obrazovati navodeći obrazloženje da su već dovoljno obrazovani, da su završili što su htjeli, ili da je za njih već kasno. Premda ne baš često, ali i dalje nešto češće nego mlađi, odrasli su spominjali želje za cjeloživotnim učenjem odgovarajući da žele stalno učiti nešto novo, da to pridonosi boljem snalaženju i stjecanju novih perspektiva. Iako ovi odgovori o nedostatku želja za daljnjim obrazovanjem nastavnika i nastavnica mogu izgledati zabrinjavajuće imajući u vidu da upravo oni trebaju biti modeli cjeloživotnoga učenja, vrlo je vjerojatno da su se mnogi usmjerili na formalno i neformalno obrazovanje kada su odgovarali na pitanje. Poslijediplomsko obrazovanje nastavnika i nastavnica u Hrvatskoj, za razliku od prethodnih razina formalnoga obrazovanja, ne financira ministarstvo zaduženo za obrazovanje tako da je to izdatak na koji se nastavnice i nastavnici rijetko odlučuju.

U odgovorima vezanima uz motivaciju za bavljenje nastavničkim poslom ili za napuštanje nastavničkog posla, rezultati potvrđuju ono što su istraživanja i ranije pokazala, a to je da su najjači motivacijski faktori oni intrinzični (Bielby et al., 2007; Čudina-Obradović, 2008) odnosno oni iz sržnih slojeva Korthagenovog modela (2004). To potkrjepljuju i odgovori nastavnica i nastavnika koji su se za tu profesiju opredijelili ranije, prepoznavši je pravom za sebe. Takva se ranija motivacija za izbor nastavničke profesije pokazuje prediktivnom za kasniji profesionalni razvoj nastavnica i nastavnika (Marušić, 2014). 


\section{Zaključak}

Nastavnici i nastavnice kao i drugi odgojno-obrazovni dionici u neprestanoj su dinamici školskih događanja, a interakcijom s okolinom aktivno sudjeluju u procesu oblikovanja i samooblikovanja. Učenici osnovnih i srednjih škola, roditelji, studenti i studentice nastavničkih studija te nastavnici i nastavnice u osnovnim i srednjim školama samorefleksijom su ukazali na potrebu utjecaja na okolinu, ponašanje, kompetencije, uvjerenja, (profesionalni) identitet i misiju. Upravo na ono što se Korthagenovim (2004) modelom smatra važnim za razvoj kompetencija nastavnika i nastavnika kako bi mogli doprinijeti sebi i kvaliteti života u svojoj zajednici. Rezultati ovoga istraživanja ukazuju na to da nastavnici i nastavnice smatraju da se nastavnički identitet tumači u okviru temeljnih vrijednosti, a učenici i roditelji više u okviru ponašanja i kompetencija. Zadaća je inicijalnoga obrazovanja nastavnika i nastavnica poticati mlade na promišljanje o vrijednostima nastavničke profesije jer će time cijeniti temeljna obilježja i vrijednosti nastavničkoga identiteta te poticati njihovu primjenu. Ranđelović i Živković (2013) ukazuju na to da je osobni razvoj najizraženiji aspekt profesionalnoga identiteta nastavnika i nastavnica, dok je najmanje izražena anticipacija uloga, što potvrđuje nužnost samorefleksije i refleksije u pripremanju mladih za rad u odgojno-obrazovnoj struci.

Rezultati upućuju na to da različiti dionici prepoznaju mnogostruke doprinose obrazovanja kvaliteti življenja i da prepoznaju da je odgojno-obrazovni proces složen, dinamičan i promjenjiv što se odražava, između ostalog, i na doživljaj statusa nastavničke profesije. Refleksije o doprinosima obrazovanja trebaju također biti popratni dio odgojnoobrazovnog procesa kao poveznice sa svrhovitošću i smislom obrazovanja.

Nekoliko je metodoloških ograničenja ovog istraživanja. Jedno od njih je prigodan uzorak u kojem su nastavnici i nastavnice bili očito pozitivno selekcionirani. No, to nije nužno nedostatak jer omogućuje uvid u razmišljanja takve pozitivnije usmjerene skupine. Drugi metodološki nedostatak uobičajen je za intervjuiranje. Iako nisu zapisivana imena, moguće je da su ipak ispitane osobe davale socijalno poželjnije odgovore. Unatoč navedenim ograničenjima, istraživanje pridonosi spoznajama iz područja refleksije o pozitivnim aspektima nastavničke profesije, obrazovanja i motivacije. 


\section{Literatura}

Baker, J. A. (1999), »Teacher-student interaction in urban at-risk classrooms: Differential behavior, relationship quality, and student satisfaction with school«, The Elementary School Journal, 100(1), str. 57-70.

Bakkenes, Inge; Jan D. Vermunt i Theo Wubbels (2010), »Teacher learning in the context of educational innovation: Learning activities and learning outcomes of experienced teachers «, Learning and Instruction, 20(6), str. 533-548. doi: https://doi.org/10.1016/j.learninstruc.2009.09.001

Bielby, Gillian; Sharp, Caroline; Shuayb, Maha; Teeman, David; Keys, Wendy i Benefield, Pauline (2007), Recruitment and Retention on Initial Teacher Training: A Systematic Review. Final Report, London: Training and Development Agency for Schools.

Bjelajac, Slobodan i Reić, Ada (2006), »Social reputation of nurse maid«, u: Ivon, Hicela (ur.), Prema kvalitetnoj školi, Split: Hrvatski pedagoško-književni zbor - Ogranak Split i Filozofski fakultet Sveučilišta u Splitu, str. 175-188.

Cooper, Karyn i Olson, Margaret R. (1996), »The multiple Ts' of teacher identity«, u: Kompf, Michael, Boak; Terence, Bond; Richard i Dworet, Don (ur.), Changing Research and Practice: Teachers' Professionalism, Identities, and Knowledge, London - Washington: Falmer Press, str. 78-89.

Čudina-Obradović, Mira (2008), Da sam ja učitelj-ica. Motivacija upisa i neke osobine studenata I. godine Učiteljskog fakulteta u Zagrebu, Zagreb: Učiteljski fakultet.

Domović, Vlatka (2011), »Učiteljska profesija i profesionalni identitet učitelja«, u: Vizek Vidović, Vlasta (ur.), Učitelji $i$ njihovi mentori, Zagreb: Institut za društvena istraživanja, str. 12-37.

Domović, Vlatka i Vizek Vidović, Vlasta (2013), »Uvjerenja studentica učiteljskoga fakulteta o ulozi učitelja, učenika i poučavanju«, Sociologija i prostor, 51(3), str. 493-508. doi: https://doi.org/10.5673/sip.51.3.3

Graham, Anne i Phelps, Renata (2003), »'Being a teacher': Developing teacher identity and enhancing practice through metacognitive and reflective learning processes«, Australian Journal of Teacher Education, 27(2), str. 11-24.

Jagić, Stjepan i Jurčić, Marko (2006), »Razredno-nastavno ozračje i zadovoljstvo učenika nastavom«, Acta Iadertina, 3, str. 29-43.

Jurić, Vladimir (1995), »Zadovoljstvo obitelji školom«, Društvena istraživanja: časopis za opća društvena pitanja, 4(4-5(18-19)), str. 641-655.

Kalin, Jana; Čepić, Renata i Šteh, Barbara (2017), »Status of teachers and the teaching profession: A study of elementary school teachers' perspectives«, u: Popov, Nikolay; Wolhuter, Charl; Kalin, Jana; Hilton, Gillian; Ogunleye, James; Niemczyk, Ewelina i Chigisheva, Oksana (ur.), BCES Conference Books 15, Sofia: Bulgarian Comparative Education Society, str. 59-65. 
Korthagen, Fred A. J. (2004), »In search of the essence of a good teacher: Towards a more holistic approach in teacher education «, Teaching and Teacher Education, 20, str. 77-97. doi: http://dx.doi.org/10.1016/j.tate.2003.10.002

Korthagen, Fred A. J. i Vasalos, Angelo (2005), »Levels in reflection: Core reflection as a means to enhance professional growth«, Teachers and Teaching, 11(1), str. 47-71. doi: https://doi.org/10.1080/1354060042000337093

Kraiger, Kurt; Ford, J. Kevin i Salas, Eduardo (1993), »Application of cognitive, skill-based, and affective theories of learning outcomes to new methods of training evaluation «, Journal of Applied Psychology, 78(2), str. 311-328. doi: 10.1037//0021-9010.78.2.311

Ledić, Jasminka; Staničić, Stjepan i Turk, Marko (2013), Kompetencije školskih pedagoga, Rijeka: Filozofski fakultet u Rijeci.

Lučić, Kata (2007), »Odgojiteljska profesija u suvremenoj odgojno-obrazovnoj ustanovi«, Odgojne znanosti, 9(1(13)), str. 151-165.

Maričić, Jelena; Šakić, Vlado i Franc, Renata (2009), »Roditeljsko zadovoljstvo školom i stav prema promjenama u školstvu: uloga roditeljskih ulaganja i očekivanih posljedica promjena«, Društvena istraživanja: časopis za opća društvena pitanja, 18(4-5(102-103)), str. 625-648.

Marušić, Milica (2014), »Da li je intrinzička motivacija profesionalnog izbora značajna za kasniji profesionalni razvoj nastavnika?«, Psihologija, 47(4), str. 449-464.

Marušić, Iris; Jugović, Iva i Pavin Ivanec, Tea (2011), »Primjena teorije vrijednosti i očekivanja u kontekstu odabira učiteljske profesije«, Psihologijske teme, 20(2), str. 299-318.

Marušić, Iris; Pavin Ivanec, Tea i Vizek Vidović, Vlasta (2010), »Neki prediktori motivacije za učenje u budućih učitelja i učiteljica«, Psihologijske teme, 19(1), str. 31-44.

Oljača, Milka; Kostović, Svetlana i Kovačević, Nataša (2015), »Samorefleksije nastavnika o profesionalnom identitetu«, Godišnjak Filozofskog fakulteta u Novom Sadu, 40(2), str. 27-45.

Pastuović, Nikola (2012), Obrazovanje i razvoj: kako obrazovanje razvija ljude $i$ mijenja društvo, a kako društvo djeluje na obrazovanje, Zagreb: Institut za društvena istraživanja u Zagrebu.

Pavin, Tea; Rijavec, Majda i Miljević-Riđički, Renata (2005), »Percepcija kvalitete učiteljskog i nastavničkog obrazovanja i nekih aspekata učiteljske i nastavničke profesije iz perspektive studenata Učiteljske akademije, visokih učiteljskih škola i nastavničkih fakulteta«, u: Vizek Vidović, Vlasta; VlahovićŠtetić, Vesna; Pavin, Tea; Rijavec, Majda; Miljević-Riđički, Renata i Žižak, Antonija (ur.), Cjeloživotno obrazovanje učitelja $i$ nastavnika: Višestruke perspektive, Zagreb: Institut za društvena istraživanja, str. 92-125. 
Peterson, Christopher i Seligman, Martin E. (2004), Character Strengths and Virtues: A Handbook and Classification (Vol. 1), Oxford: University Press.

Plavšić, Marlena i Diković, Marina (2016), „Students' attitudes toward formal education, non-formal and informal learning «, Croatian Journal of Education: Hrvatski časopis za odgoj i obrazovanje, 18(1), str. 71-102.

Raboteg-Šarić, Zora; Brajša-Žganec, Andreja i Šakić, Marija (2009), »Life satisfaction in adolescents: The effects of perceived family economic status, selfesteem and quality of family and peer relationships«, Društvena istraživanja: časopis za opća društvena pitanja, 18(3(101)), str. 547-564.

Radeka, Igor i Sorić, Izabela (2006), »Zadovoljstvo poslom i profesionalni status nastavnika«, Napredak, 147(2), str. 161-177.

Ranđelović, Dušan i Živković, Predrag (2013), »Korelati profesionalnog identiteta nastavnika«, Teme - časopis za društvene nauke, 37(2), str. 647-666.

Reić Ercegovac, Ina i Jukić, Tonća (2008), »Zadovoljstvo studijem i motivi upisa na studij«, Napredak: časopis za pedagogijsku teoriju i praksu, 149(3), str. 283-295.

Sharma, R. D. i Jyoti, Jeevan (2006), »Job satisfaction among school teachers«, IIMB Management Review, 18(4), str. 349-363.

Skaalvik, Einar M. i Skaalvik, Sidsel (2011), »Teacher job satisfaction and motivation to leave the teaching profession: Relations with school context, feeling of belonging, and emotional exhaustion«, Teaching and Teacher Education, 27(6), str. 1029-1038.

Šimić Šašić, Slavica; Klarin, Mira i Grbin, Kristina (2013), »Motivacija za učiteljski poziv, zadovoljstvo studijem i zadovoljstvo izborom zanimanja«, Magistra Iadertina, 8(1), str. 7-27.

TALIS (2013), Results: An International Perspective on Teaching and Learning. Dostupno na: http://www.oecd.org/edu/school/talis-2013-results.htm [15. 5. 2018.]

Williams, Geoffrey C. i Deci, Edward L. (1996), »Internalization of biopsychosocial values by medical students: a test of self-determination theory«, Journal of Personality and Social Psychology, 70(4), str. 767.

Zakon o odgoju i obrazovanju u osnovnoj i srednjoj školi, NN 87/08. 


\title{
EDUCATIONAL VALUES AND TEACHER'S IDENTITY FROM STUDENTS, PARENTS AND TEACHERS' PERSPECTIVE
}

\author{
Marina Diković, Marlena Plavšić
}

In Croatia, as well as around the world, teachers would rarely describe their profession as respected in the society. Most authors agree that the strengthening of the teacher's identity might help in elevating the perceived value and the overall status of education. The objectives of this study are: to identify ways in which education increases the quality of life, to explore perception of teaching profession status, to examine the perception of both the teaching profession and changes in the educational system and, finally, to determine the motivation for becoming a teacher. The sample comprises 74 primary and secondary school students, 73 parents, 38 students of teacher studies and 35 primary and secondary school teachers. Results were interpreted in the context of Korthagen's model. Results show that teachers view teacher's identity as connected to the core values, while parents and students describe the teacher's identity through characteristics related to behaviour and competences. The task of the initial teacher education is to encourage students to reflect upon the values of the teaching profession. Such reflection helps in building the core values of the teacher's identity and increases one's appreciation of it.

Key words: teaching profession, Korthagen's model, teachers, teacher's identity, parents, students 